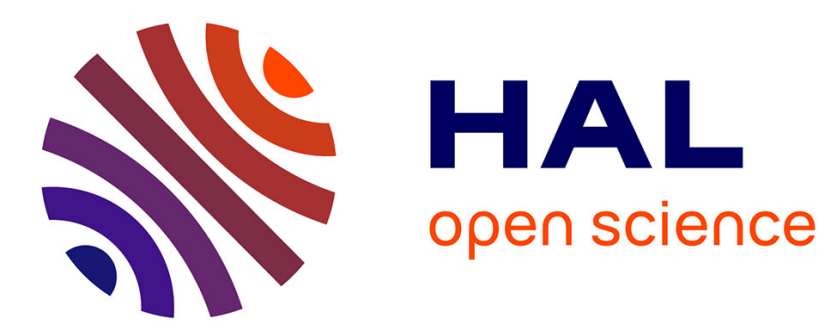

\title{
Iles Eparses (SW Indian Ocean) as reference ecosystems for environmental research
}

C. Quétel, Sébastien Marinesque, David Ringler, L. Fillinger, T. Changeux, C. Marteau, M. Troussellier

\section{- To cite this version:}

C. Quétel, Sébastien Marinesque, David Ringler, L. Fillinger, T. Changeux, et al.. Iles Eparses (SW Indian Ocean) as reference ecosystems for environmental research. Acta Oecologica, 2016, 72, 10.1016/j.actao.2015.12.012 . hal-01286531

\section{HAL Id: hal-01286531 https://hal.science/hal-01286531}

Submitted on 9 Jun 2020

HAL is a multi-disciplinary open access archive for the deposit and dissemination of scientific research documents, whether they are published or not. The documents may come from teaching and research institutions in France or abroad, or from public or private research centers.
L'archive ouverte pluridisciplinaire HAL, est destinée au dépôt et à la diffusion de documents scientifiques de niveau recherche, publiés ou non, émanant des établissements d'enseignement et de recherche français ou étrangers, des laboratoires publics ou privés. 
archives-ouvertes

\title{
Iles Eparses (SW Indian Ocean) as reference ecosystems for environmental research
}

\author{
C. Quétel, S. Marinesque, D. Ringler, L. Fillinger, T. Changeux, C. Marteau,
} M. Troussellier

\section{To cite this version:}

C. Quétel, S. Marinesque, D. Ringler, L. Fillinger, T. Changeux, et al.. Iles Eparses (SW Indian Ocean) as reference ecosystems for environmental research. Acta Oecologica, Elsevier, 2016, 72, 10.1016/j.actao.2015.12.012 . hal-01286531

\section{HAL Id: hal-01286531 \\ https://hal.archives-ouvertes.fr/hal-01286531}

Submitted on 9 Jun 2020

HAL is a multi-disciplinary open access archive for the deposit and dissemination of scientific research documents, whether they are published or not. The documents may come from teaching and research institutions in France or abroad, or from public or private research centers.
L'archive ouverte pluridisciplinaire HAL, est destinée au dépôt et à la diffusion de documents scientifiques de niveau recherche, publiés ou non, émanant des établissements d'enseignement et de recherche français ou étrangers, des laboratoires publics ou privés. 


\title{
Iles Eparses (SW Indian Ocean) as reference ecosystems for environmental research
}

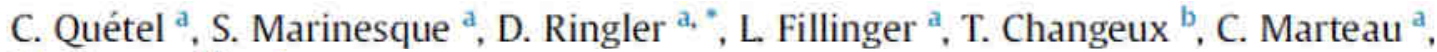 \\ M. Troussellier ${ }^{c}$ \\ ${ }^{2}$ Terres australes et antarctiques francaises (TAMF), 1 rue Gabriel Dejean, B.P 400, 97458 Saint Pierre Cedex, France \\ b Institut de recherche pour le developpement (IRD), Le Sextant, 44 boulevard de Dunkerque, CS90009, 13572 Marseille Cedex 02 , France \\ ' UMR 9190 MARBEC UM2-CNRS-IRD-UM1-IFREMER, CC 93, Place Eugène Bataillon, Université de Montpellier, F-34095 Montpellier, France
}

\section{A R T I C LE I N F O}

\section{Article history:}

Received 22 December 2015

Received in revised form

28 December 2015

Accepted 28 December 2015

Available online 8 january 2016

\section{Keywords:}

lles Eparses

Indian ocean

Environmental research

Pristine ecosystems

Biodiversity sanctuaries

Climate change

\begin{abstract}
A B S T R A C T
TAAF ensures since 2007 the management of 5 small tropical islands lying in the southwestern Indian Ocean: the lles Eparses. These islands share an exceptional natural heritage including many marine and terrestrial endemic species. At a regional scale the lles Eparses are some of the most pristine ecosystems, largely preserved from anthropogenic impacts due to their geographical isolation and a historically very limited human occupation. In this context. TAAF wished that lles Eparses become unique natural laboratories for earth scientists and environmental process observation - like climate change impacts - but also sustainable biodiversity sanctuaries for which the scientific community should provide baseline ecological data to inform on appropriate conservation tools. An inter-agency research consortium emerged in 2009 to meet this commitment for the lles Eparses. This program was intended to set a science framework in accordance with France objectives for Research and Conservation. It enabled between 2009 and 2014 the implementation of 18 cross-disciplinary research projects ranging from geology to ecology and represented by the variety of the proposed articles in this special issue. Altogether research projects have dramatically increased knowledge on the lles Eparses' ecosystems and have provided the first overview of their diversity, their functions and their dynamics and its determinants. In particular applied research efforts have supplied a significant amount of ecological evidence that is now available to develop optimal conservation strategy to ensure the lles Eparses' long-term biodiversity value. These findings point out that the continuation of research activity in the lles Eparses should be concidered a nrinritu
\end{abstract}

\section{Iles Eparses overview}

The lles Eparses are a collection of French overseas island territories in the Western Indian Ocean managed by the French Southem and Antarctic Lands (French: Terres Australes et Antarctiques Françaises, TAAF, Box. 1) since February 2007 (fifth district of TAAF along with Kerguelen, Crozet, Saint Paul and Amsterdam, and the Terre Adélie). They are composed of the following islands: Europa, Juan de Nova and Glorieuses archipelago (Grande Glorieuse, Roches Vertes and lle du Lys) in the Mozambique Channel (lying between $11^{\circ} \mathrm{S}$ and $22^{\circ} \mathrm{S}$ ), and Tromelin north of La Reunion. The barely emerged coral reef Bassas da India is also included

\footnotetext{
- Corresponding author.

E-mail address: david.ringleretadffr (D. Ringler).
}

within the lles Eparses (Table 1 and Fig. 1).

All islands except Juan de Nova were classified as nature reserves in 1975. While the combined land area of the islands does not exceed $42 \mathrm{~km}^{2}$, associated territorial marine waters represent a total of more than $640,000 \mathrm{~km}^{2}$ (approximately $6 \%$ of the French maritime territory) (Table 1). The lles Eparses are distributed along a climatic gradient ranging from sub-arid climate (Europa) to a more tropical wet climate (Glorieuses). Climate is characterized by the alternation of a warm and wet season (austral summer, from December to April) and a dry and cooler season (austral winter. from April to October). The lles Eparses are all located in the regional pathways of depressions and tropical cyclones. In the Mozambique Channel, ocean currents are subjected to a very high spatial and temporal variability associated with the presence of many gyres (Schouten et al., 2003; Calzas, unpub. data). These oceanographic features significantly influence the dispersal ability 
Box 1

. TAAF Administr ative organization.

TAAF are placed under the authority of a senior adminis trator, who is designated since 2005 among the body of prefects. The prefect is both the government representative and the executive authority for the administration. TAAF present the particularity of having no permanent population and therefore have neither voters nor elected representatives or local deliberative assembly. The Prefect can nonetheless rely on a Consultative Committee and is assisted by a Secretary General, a Chief of Staff, several District Commanders and numerous project managers. The Prefect is empowered to manage all resources of the territory and more specifically to ensure the sustainable management of fisheries. In particular he is responsible for managing fish stocks within its territory and thus is in charge of editing fisheries guidelines, delivering fishing licenses, fixing the total allowable catches (TAC) as well as the dates for fisheries opening, and finally of setting and raising fishing fees. The prefect is, amongst other things, bound to guaranty the environmental conservation. TAAF regulations therefore mostly aim to provide a better framework for human activities based on up-to-date scientific knowledge and in compliance with national or regional regulations (e.g. IOTC, CITES). to stay on the islands, respectively, in the context of their research projects and their land management missions.

\section{Biodiversity sanctuaries}

The lles Eparses are among the last sanctuaries of marine and terrestrial tropical biodiversity in the South Westem Indian Ocean. Geographic isolation and historically very limited human occupation have largely preserved these territories. Despite the introduction of some exotic species they are home to a remarkable native flora and fauna (including many endemic species) and wellpreserved complex ecosystems such as mangroves and coral reefs. Each island supports high levels of species richness (Table 2) some being endemic to these ecosystems and others reaching vely high densities. For example. Europa is a breeding ground for 8 seabird species including one endemic tropicbird species (Phaethon lepcurus europae) and Juan de Nova is hosting one of the largest sooty tern colonies in the Indian Ocean ( 500000 breeding pairs. Orlowski et al., unpub. data). Many reptiles and terrestrial birds, such as the Snake-eyed Skinks (Cryptoblepharus bitaeniatus) and the Malagasy White-eye (Zosterops maderaspatanus ssp. voeltzkowii), are also endemic to these islands (Probst, 1997: Sanchez and Probst. 2014). The lles Eparses are major breeding sites for endangered marine turtles (Chelonia mydas and Eretmochelys imbricata). Europa is especially regarded as the most frequented site by breeding females in the Indian Ocean (8000-10000 each year, Bourjea et al., 2011). The lles Eparses are also regionally important refuges for large

Tuble 1

Main geographic cluaracteristics of the lles Eparses (surfsce of geomorphologic units: Andr fouct es . 1 .. 2008).

\begin{tabular}{|c|c|c|c|c|c|c|c|}
\hline & \multirow[t]{2}{*}{ Troinclin } & \multicolumn{2}{|l|}{ Glorieuses } & \multirow[t]{2}{*}{ Juan de Nova } & \multirow[t]{2}{*}{ Bassas da India } & \multirow[t]{2}{*}{ Europa } & \multirow[t]{2}{*}{ Tonal } \\
\hline & & Clorieuses arthipelago & Geyser Banks & & & & \\
\hline \multirow[t]{2}{*}{ Geographical coordinates } & $15 \div 53^{\prime} \mathrm{S}$ & $11: 35 ' 5$ & $22: 21: 5$ & $1703^{\prime} \mathrm{S}$ & $21 * 285$ & $222^{\prime} 21^{\prime} \mathrm{s}$ & \\
\hline & $54 \cdot 31^{\prime} \mathrm{E}$ & $47 * 18 \mathrm{E}$ & $40^{\prime} 21^{\prime} \mathrm{E}$ & $42^{\prime} 43^{\prime} \mathrm{E}$ & $39.42 \mathrm{E}$ & $40^{\circ} 21^{\prime} \mathrm{E}$ & \\
\hline EEZ surface $\left(\mathrm{km}^{2}\right)$ & 285300 & 43614 & & 61050 & 123700 & 127300 & $640 / 964$ \\
\hline Surface of each geomorphologic unir $\left(\mathrm{km}^{2}\right)$ & 6.9 & 201.36 & 256.79 & 212.17 & 96.33 & 49.13 & 82268 \\
\hline Land-mass & 0.85 & 4.79 & - & 5.48 & 0.1 & 31.63 & 42.85 \\
\hline Coral reef & 5.42 & 26.92 & 47.8 & 43.47 & 49.18 & 10.50 & 183.29 \\
\hline Lagoon & 0.63 & 169.65 & 20899 & 16322 & 47.05 & 7 & 596.54 \\
\hline
\end{tabular}

(larval and adult) and recruitment and thus the connectivity of many marine species (Bourjea et al.. 2007; Muths et at., 2011, 2012; Visram et a L. 2010). Ocean eddies also have a strong influence on the distribution of primaly production areas and therefore that of associated top predator species like tuna and seabirds (Weimerskirch et al., 2004).

The lles Eparses were discovered by Europeans in the sixteenth century. Several attempts of human settlements on the islands took place in the past but all were unsuccessful mainly due to the lack of freshwater and harsh living conditions. These occupations were responsible for the introduction of exotic animal and plant species. some of which are now invasive such as black rats (Rutrus rattus). cats (Felis catus). Mauritius hemp (Furcraea foetida) or Australian pines (Casuarina equisetifolia). The exploitation of guano and copra on Grande Clorieuse and Juan de Nova also generated the disappearance of some native terrestrial habitats. Today. the lles Eparses do not house permanent human populations. However. Grande Clorieuse, Europa and Juan de Nova have been occupied year-round since 1973 by rotating military detachments ( 15 people including one gendarme ) every 45 days in order to ensure Prench sovereignty. Similarly on Tromelin three TAAF agents take turns on the island every 2 months. Scientists and TAAF officers are regularly required number of migratory species (shorebirds, raptors, etc.) often facing severe threats along their migratory roads. The Mozambique Channel and especially the lles Eparses exclusive economic zones (EEZs) are also frequented by many species of marine mammals and fishes. In particular several species of sharks and rays. benefiting from protection measures under various intemational treaties and conventions (Bonn. Washington Convention CITES International Whaling Convention. Nairobi Convention) cross off the islands year-round. While the sampling effort of marine fauna and flora was not the same for the different taxonomic group and for each island. the present known marine biodiversity is very large. For example, the lles Eparses hartor near 10\% of fish species richness of the Westem Indian Ocean area (Heemstra, unpub. data).

\section{Anthropogenic pressures and threats}

Although lles Eparses natural ecosystems have been little altered over the past centuries. they are now facing numerous threats. These threats, resulting from climatic phenomena or from past and present human activities. are commonly encountered with varying intensities in tropical islands. In the lles Eparses, the level of pressure exerted on the ecosystems highly varies from an island to 


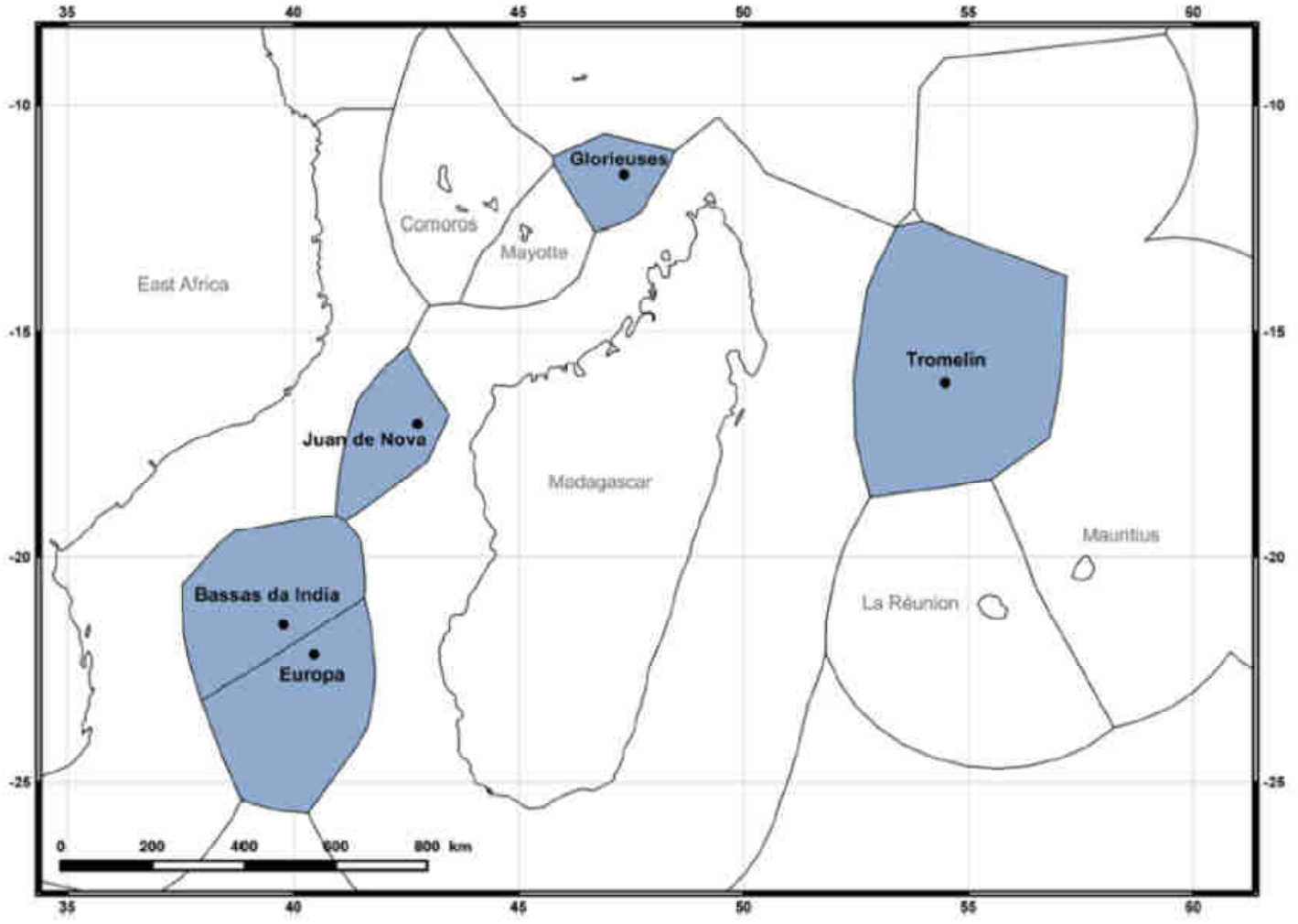

Fig. 1. Map of the lles Eparses showing their location and the extent of their associated EEZs.

another depending on the history (past human occupation), geographical location and accessibility as well as on the richness of the marine resources (overview in Table 3).

Climate change, cyclones and pollution represent an approximatively equal threat to all islands, Tromelin being slightly more exposed to cyclones. The effects of these threats on terrestrial and marine ecosystems will be monitored in each island in the coming years, with a special emphasis on the direct and indirect impacts of climate change (e.g. Chabanet et al., 2015). The results of this monitoring could be integrated to models in order to quantify, understand and predict the future effects of climate change on the islands. Models could also be extended to more complex ecosystems in the region, for example on similar sites exposed to a higher anthropogenic influence. TAAF have little resources to counter these global threats and so that their actions focus on conservation issues related to activities happening on or around the islands and building resilient ecosystems.

On all islands (except Bassas da India) the main threat to terrestrial ecosystems is the presence of alien invasive species. In fact, several animals and plants have been introduced throughout the recurring attempts to establish human settlements on the lles Eparses over the past centuries. This heritage from past human activities has led to ecological disturbances of the original ecosystems (e.g. Russell and Le Corre, 2009). It has induced changes in biological interactions such as an increased predation pressure on native species (e.g. breeding seabirds, terrestrial endemic reptiles) as well as important modifications of the vegetation dynamics, resulting in the alteration of natural habitats and possibly leading to the extinction of native species (Le Corre et al., 2015; Ringler et al., 2015). The TAAF implement numerous programs and campaigns on each island to control or eradicate invasive species as well as to prevent new introductions (biosecurity plans). These programs are built upon the last available knowledge on ecosystems functioning, resulting notably from research projects conducted in the fles Eparses (e.g. Le Corre et al., 2015; Ringler et al., 2014, 2015). Programs currently running concern mostly, but not exclusively, (i) invasive species impacts assessment (feral goats on Europa and Australian pines on Grande Glorieuses), (ii) management strategy design (rats on all islands) and (iii) eradication operations implementation (Mauritius hemp on Europa and feral cats on Juan de Nova).

Historically limited to the islands themselves, human activities are now turned towards the marine environment and expand over the entire EEZ. The exceptionally rich marine resources are very attractive and their exploitation represents a new source of pressures and issues. An industrial fishery mainly targeting tropical tuna and spearfish is authorized in the outer part of the EEZ (Fig. 2). This fishery is strictly prohibited within the 12 nautical mile limit (territorial sea) of the lles Eparses. Outside of the territorial waters, it is submitted to the deliverance of a license by TAAF. This high-sea fishery is mainly operated by French and Spanish seiners. Their activities are regulated by technical prescriptions. These guidelines aim at a sustainable use of the resources and a reduction of the impacts on the ecosystems. Despite a strict frame, the tuna fishery still generates high rates of by-catch (Bourjea et al, 2008; Poisson et al., 2014), especially when practiced over fish aggregating devices (FADs) (Amandè et al., 2008a, 2008b; Amandé et al., 2012; Chavance et al, 2011). Beside pelagic fishes, coral-reef associated species also are threatened. Coral reefs surrounding the islands or located within their EEZ (e.g. Geyser Bank within the Glorieuses EEZ) concentrate high densities of commercial fishes (Le Manach and Pauly, 2015: Wickel et al., 2009). A significant human population growth in the region (Pison, 2015) has generated a high demand for fish on the local markets of Mayotte, Madagascar and the 
Number of species identified on each island and for each taxonomic group (non-exhaustive dataset).

\begin{tabular}{|c|c|c|c|c|c|c|}
\hline & \multirow[t]{2}{*}{ Tromelin } & \multicolumn{2}{|l|}{ Glorieuses } & \multirow[t]{2}{*}{ Juan de Nova } & \multirow[t]{2}{*}{ Bassas da India } & \multirow[t]{2}{*}{ Europ. } \\
\hline & & Glorieuses archipelago & Geyser Banks & & & \\
\hline \multicolumn{7}{|l|}{ Terrestrial biodiversity } \\
\hline Habitats & 2 & 9 & NR & 12 & NR & 8 \\
\hline Flora ${ }^{1}$ & 17 & 121 & NR & 147 & NR & 90 \\
\hline Arthropods ${ }^{2}$ & 31 & 180 & NR & 83 & NR & 103 \\
\hline Terrestrial reptiles ${ }^{3}$ & 1 & 4 & NR & 3 & NR & 4 \\
\hline Terrestrial mammals (introduced) ${ }^{4}$ & 2 & 2 & NR & 3 & NR & 2 \\
\hline \multirow{2}{*}{ Terrestrial avifauna (breeding) ${ }^{4}$} & 0 & 9 & NR & 4 & NR & 5 \\
\hline & 53 & 325 & NR & 252 & NR & 212 \\
\hline \multicolumn{7}{|l|}{ Marine biodiversity } \\
\hline Plankton ${ }^{5}$ & 18 & 179 & - & - & - & 18 \\
\hline Algae $^{6}$ & - & 215 & - & 36 & - & 134 \\
\hline Phanerogams & - & 6 & 2 & - & - & 5 \\
\hline Sponges & - & - & - & 15 & $=$ & 24 \\
\hline Cnidarians $^{7-10}$ & 26 & 110 & 37 & 256 & 15 & 125 \\
\hline Bryozoans & - & 95 & - & - & - & 28 \\
\hline Brachiopods & - & - & - & - & - & - \\
\hline Echinoderms ${ }^{9-12}$ & 1 & 54 & 30 & 23 & - & 39 \\
\hline Molluses $^{10}$ & - & 247 & 124 & 168 & - & 14 \\
\hline Arthropods ${ }^{13}$ & - & 157 & - & 13 & - & 176 \\
\hline Tunicates & - & - & - & - & - & 15 \\
\hline Bony fishes (osteichtyans) $10,14-19$ & 95 & 349 & 388 & 299 & 301 & 380 \\
\hline Cartilaginous fishes (chondrichtyans) & - & 14 & 14 & 17 & 10 & 16 \\
\hline Marine mammals $22-24$ & 2 & 5 & 5 & 5 & 2 & 7 \\
\hline Marine turtles ${ }^{2}$ & 1 & 2 & NR & 2 & NR & 2 \\
\hline \multirow[t]{2}{*}{ Seabirds (breeding) ${ }^{4}$} & 4 & 2 & NR & 2 & NR & 8 \\
\hline & 147 & 1435 & 600 & 836 & 328 & 995 \\
\hline TOTAL & 200 & 1760 & 600 & 1088 & 328 & 1207 \\
\hline
\end{tabular}

- : no data available.

NR: not relevant.

${ }^{3} \mathrm{CBNM}, 2013 ;{ }^{2}$ Parnaudeau, 2008; ${ }^{3}$ Probse, 1999; ${ }^{4}$ Caceres, 2003; ${ }^{5}$ Bartistini et al., 1976; ${ }^{6}$ Mattio and Zubia, 2012; ${ }^{7}$ Gravier-Bonnet and Bourmaud, $2004 ;{ }^{8}$ Gravier-Bonnet and Bourmaud, 2006: ${ }^{9}$ Quod and Garnier, 2004; ${ }^{10}$ Quod et aL, 2007: ${ }^{9}$ Conand et al., 2013a, 2013b; ${ }^{10}$ Conand et al., 2013a., $2013 \mathrm{~b}:{ }^{11}$ Mulochau et al., 2007: ${ }^{27}$ Mulochau and Conand, 2009: ${ }^{13}$ Poupin et al., 2012: ${ }^{14}$ Chabanet et al., 2002: ${ }^{15}$ Chabane and Durvilk, 2005: ${ }^{16}$ Durville et aL. 2003: ${ }^{17}$ Durville \& Chabanet. 2010: ${ }^{18}$ Fricke et al., 2013: ${ }^{19}$ Wickel et al., 2009; ${ }^{20}$ Kiszka et al., 2009a; ${ }^{21}$ Wickel et al., 2010; ${ }^{2}$ Ersts et al., 2011; ${ }^{23}$ Kiszka et al., 2009b; ${ }^{24}$ Laran et al., $2012 ;{ }^{25}$ Bourjea er al., 2011.

Comoros, resulting in high pressure on marine resources and decreasing catches. In response to the decrease of resource in the region, fishermen are now turning to the lles Eparses, concentrating their efforts on the Geyser Bank and the other reefs around the Glorieuses archipelago, where fishing is strictly prohibited. Glorieuses and Juan de Nova are also submitted to the poaching of sea-cucumbers, organized from Madagascar to supply the Asian market (Conand et al., 2013b).

Despite these pressures on the marine environment, the unique natural heritage of the lles Eparses remains very attractive for tourism and leisure activities. Those are mostly related to (i) the exploration of the marine natural heritage (snorkeling and SCUBA diving), (ii) sailing and (iii) recreational fishery. This latter is strictly forbidden but yet occurs in Bassas da India's EEZ supported by South African and Mozambican charter companies (Le Manach and Pauly, 2015). Although the number of requests to access the lles Eparses (subject to authorization) has increased over the last years (Fig. 2), the majority of tourism and leisure activities actually happening on TAAF territory do not request prior authorization. Unauthorized and therefore uncontrolled activities generally come from neighboring islands (Mayotte, Madagascar) and from eastern Africa (Mozambique and South Africa) and may affect marine ecosystems.

Recent surveys have revealed that the Mozambique Channel may be rich in oil and gas resources (Brownfield et al., 2012). It could also represent a potential reservoir of polymetallic nodules, genetic resources or bioactive molecules. Waters under French jurisdiction around Europa, Bassas da India, Juan de Nova and the Glorieuses archipelago represent half of the area of the Mozambique Channel. Beside the risk for the terrestrial and marine ecosystems associated to the exploitation of such resources, these findings could also refuel territorial claims over the lles Eparses. This would threaten the sovereignty of france over the islands, which is nowadays the only warranty for the preservation of their exceptional natural heritage.

\section{Conciliating biodiversity conservation and sustainable development}

With an exceptional biodiversity and a preserved environment. the lles Eparses represent a unique opportunity for the French government to fulfill its national and international commitments in terms of sustainable development and biodiversity conservation. TAAF also play a key role in the national strategy aiming at the constitution of a regional network of protected areas. Relying on their experience in the lles Australes (since 1955), TAAF are currently elaborating a sustainable management model for the lles Eparses based on a strong synergy between stakeholders and the scientific community. The acquisition of basic environmental knowledge represents a stepping stone for efficient management strategy. As such, TAAF promote long-term research projects to (i) understand ecosystems functioning (ii) establish evolution scenarios, (iii) identify impacts and threats resulting from human activities and (iv) build indicators of ecosystem health. Beside the acquisition of knowledge for management purposes, the TAAF intend to systematically supervise and control human activities in the lles Eparses in order to reduce their potential impact on ecosystems. Technical prescriptions are regularly edited and updated to regulate tuna fishery, tourism and oil and gas resources prospection missions. 
Table 3

Type and level of pressure identified for each island with the potential impact on natural ecosystems.

\begin{tabular}{|c|c|c|c|c|c|c|c|}
\hline \multicolumn{2}{|l|}{ Pressure type } & \multirow{3}{*}{$\begin{array}{l}\text { Potential impacts } \\
\text { Overfishing and/or overexploitation of pelagic resources } \\
\text { By-catch and incidental catch }\end{array}$} & \multicolumn{5}{|c|}{ Level of pressure } \\
\hline & & & \multirow{2}{*}{$\begin{array}{l}\text { Tromelin } \\
\text { medium }\end{array}$} & \multirow{2}{*}{$\begin{array}{l}\text { Glorieuses } \\
\text { medium }\end{array}$} & \multirow{2}{*}{$\begin{array}{l}\text { Juan de } \\
\text { Nova } \\
\text { medium }\end{array}$} & \multirow{2}{*}{$\begin{array}{l}\begin{array}{l}\text { Bassas } \\
\text { da India }\end{array} \\
\text { medium }\end{array}$} & \multirow{2}{*}{$\begin{array}{l}\text { Europa } \\
\text { medium }\end{array}$} \\
\hline Large pelagic industrial fishery (tuna & fishery) & & & & & & \\
\hline \multicolumn{2}{|c|}{ Artisanal and semi-industrial reef fishery } & Overfishing and/or overexploitation of reef resources & none & high & none & none & none \\
\hline \multirow[t]{3}{*}{$\begin{array}{l}\text { Hllegal, unreported and unregulated } \\
\text { (IUU) fisheries and poaching }\end{array}$} & $\begin{array}{l}\text { IUU artisanal reef } \\
\text { fishery }\end{array}$ & Overfishing and/or overexploitation of reef resources & none & medium & medium & none & none \\
\hline & Holothurian fishery & Collapse of holothurian stocks & none & high & high & none & none \\
\hline & $\begin{array}{l}\text { Marine turtles } \\
\text { poaching }\end{array}$ & Decrease in marine turtle populations & none & low & none & none & none \\
\hline \multirow[t]{4}{*}{ Recreational activities and tourism } & Fishing/spearfishing & Overfishing and/or overexploitation of marine resources & none & high & low & high & low \\
\hline & $\begin{array}{l}\text { Scubadiving/ } \\
\text { Snorkeling }\end{array}$ & Disturbance of marine wildlife & none & high & fow & high & low \\
\hline & $\begin{array}{l}\text { Anchoring on coral } \\
\text { reef }\end{array}$ & Coral reef destruction Spread of coral diseases & none & high & low & low & low \\
\hline & Landbased tourism & Disturbance of terrestrial wildlife Vegetation trampling & low & low & low & NR & low \\
\hline Maritime traffic & & Oil pollution & low & low & medium & low & low \\
\hline \multirow[t]{2}{*}{ Mining activities } & Prospection & Acoustic pollution & NR & low & high & none & none \\
\hline & $\begin{array}{l}\text { Exploitation (in the } \\
\text { long term?) }\end{array}$ & $\begin{array}{l}\text { Oilspill/hydrocarbons pollution/deepsea ecosystems } \\
\text { degradation }\end{array}$ & NR & none & none & none & none \\
\hline \multirow{2}{*}{\multicolumn{2}{|c|}{ Macro-wastes }} & Loss of natural value of the istand & medium & low & low & none & low \\
\hline & & $\begin{array}{l}\text { Mortality of top predators including marine turtles } \\
\text { (ingestion of plastic waste, entanglement, etc.) }\end{array}$ & medium & medium & medium & mediurn & medium \\
\hline \multirow{4}{*}{\multicolumn{2}{|c|}{ Landbased pollution }} & Chemical pollution & low & low & low & NR & low \\
\hline & & Loss of natural value of the island & low & low & low & NR & low \\
\hline & & Fires & medium & medium & medium & $N R$ & medium \\
\hline & & Spread of invasive anthropophilic species & medium & low & low & NR & medium \\
\hline \multirow{4}{*}{\multicolumn{2}{|c|}{$\begin{array}{l}\text { Looting of underwater cultural heritage } \\
\text { Cyclones }\end{array}$}} & Loss of cultural heritage & NR & NR & NR & high & NR \\
\hline & & Destruction of vegetation & high & medium & medium & $N R$ & medium \\
\hline & & Beaches and sand dunes erosion & high & medium & medium & NR & medium \\
\hline & & Coral reef destruction & low & low & low & medium & low \\
\hline \multirow[t]{7}{*}{ Cimate Change } & $\begin{array}{l}\text { Warming of marine } \\
\text { waters }\end{array}$ & Coral bleaching & low & medium & medium & medium & low \\
\hline & Intensification of & Destruction of vegetation & high & medium & medium & NR & medium \\
\hline & tropical cyclones & Beaches and sand dunes erosion & high & medium & medium & $N R$ & medium \\
\hline & & Coral reef destruction & none & none & none & low & none \\
\hline & Ocean acidification & Slowdown in coral and zooplancton growth & low & bw & low & low & low \\
\hline & Sea level rise & Loss of nesting beaches surface (for turtles) & low & low & low & NR & low \\
\hline & $\begin{array}{l}\text { Atmospheric } \\
\text { temperature rise }\end{array}$ & $\begin{array}{l}\text { Modification of sex-ratio and survival rates in marine } \\
\text { turtles hatchlings populations }\end{array}$ & medium & medium & medium & NR & medium \\
\hline \multirow{2}{*}{\multicolumn{2}{|c|}{ Exotic and/or invasive species }} & Increase in the predation pressure on native species & low & high & high & NR & high \\
\hline & & Changes in vegetation communities & low & high & high & NR & high \\
\hline \multicolumn{2}{|l|}{ Native anthropophilic species } & Spread of anthropophilic species & medium & low & low & NR & medium \\
\hline
\end{tabular}

: no data available.

NR: not relevant.

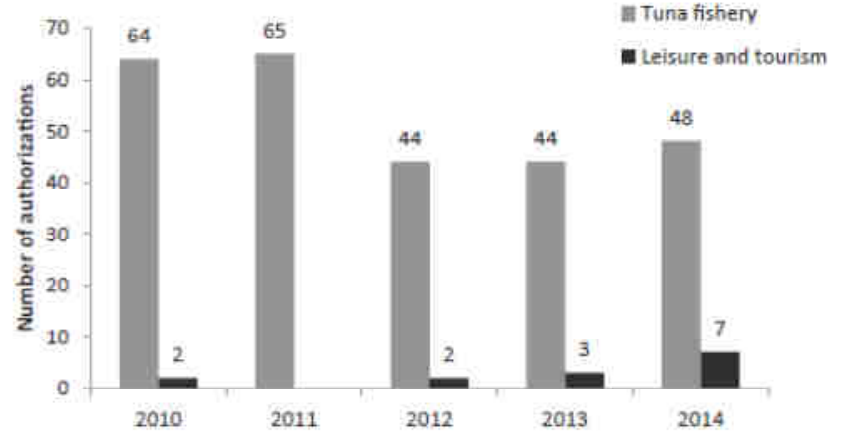

Fig. 2. Legal activities: evolution in the lles Eparses between 2010 and 2014 (TAAF. unpub, data).

TAAF have built a strategy for the classification of the lles Eparses as protected areas. Different conservation statuses exist, fixing a legal frame for the preservation of specific areas, habitats or species. TAAF must thus identify the most adapted conservation tools for each island, submits application files for their classification and implement the resulting management plans. Europa and its territorial waters were recognized in 2011 as the 42 nd Wetlands of international importance according to the RAMSAR Convention (www.ramsar.org). Europa is also registered within the "Network of Sites of Importance for Marine Turtles" of the Indian Ocean - SouthEast Asian Marine Turtle Memorandum of Understanding (IOSEA MoU) since 2014 (www.ioseaturtle.org) and will soon become a national nature reserve. A Natural marine park ("Parc naturel marin des Glorieuses") has been created in 2012, covering the entire EEZ of the Glorieuses Archipelago (www.taaffr and www.airesmarines.fr). It provides TAAF with an official tool to preserve the marine environment around the islands and to simultaneously develop sustainable human activities (tuna and artisanal fishery. tourism). The management plan built for the next 15 years includes several actions related to the acquisition of knowledge, the conservation of ecosystems, education and training. sustainable development, exploitation and surveillance.

\section{Reference ecosystems for global research}

The international scientific community considers the geographical location and the conservation status of the lles 
Eparses provide a unique support for the development of crossdisciplinary research (Obura et al., 2012). Beyond the development of research in the tropics, the addition of the lles Eparses as research sites promotes, within a single French public authority (TAAF), the setting up of large scale studies along a latitudinal gradient that extends from $11^{\circ} \mathrm{S}$ (Glorieuses) to $66^{\circ} \mathrm{S}$ (Terre Adélie). With an exceptional coverage of more than $80 \%$ of the Southern Hemisphere, TAAF offer a convenient and unique location for the establishment of an observatory on biodiversity and climate change impacts.

Following a conference organized at the French Senate in 2009 , an inter-agency research consortium dedicated to the lles Eparses was established in 2010. This consortium was driven and supported by the French National Center for Scientific Research (CNRS), the TAAF, the French Agency for Marine Protected Areas (AAMP) and the French Institute of Research for the Development (IRD), in partnership with the French Polar Institute "Paul Emile Victor" (IPEV), the French National Museum of Natural History (MNHN) and the French Research Institute for Exploitation of the Sea (IFREMER). Foundation of a consistent research framework was proposed for the lles Eparses over the period 2010-2013 and beyond. With financial support of the consortium members, FAZSOI material support (transportation and accommodation) and the logistical support of the TAAF (coordination of scientific missions and provision of research vessel 'Marion Dufresne' in 2011), 18 research programs and nearly 120 field missions were carried out between 2011 and 2014.

This special issue of Acta Oecologica includes papers showing the diversity of these research projects. A large part of the research work concerned marine biological diversity exploration. Several projects were dedicated to the first description of the diversity of different communities: pelagic microorganisms (Bouvy et al.. 2015). benthic cyanobacteria (Zubia et al., 2015), marine macrophytes (Mattio et al., 2015). Others allowed to complete previous inventories of marine fauna (Crustacea: Poupin, 2015; Echinoderms: Conand et al,, 2015) and/or to get new data to compare the diversity of coral and fishes communities of lles Eparses to the ones of other areas of WIO (Chabanet et al., 2015). Not only species richness of the studied marine communities exhibited large values, but also biomass of upper trophic compartments such as fishes reach exceptional high values compared to other values reported in the WIO. Added to data from previous studies, the ones obtained on the lles Eparses fish fauna allowed to assess both the level of their endemism in the WIO, which was higher than in any other region of the Indian Ocean, and to explore their evolutionary dynamics at the regional scale (Borsa et al., 2015).

The knowledge of the terrestrial vascular flora richness of the Iles Eparses was also improved through several fieldwork missions supported by the program (Boullet, unpub. data): 236 taxa were now reported for the lles Eparses. The composition of the flora of each island appeared to be greatly influenced by their geographical location that correspond to different climatic conditions and distances from the main pool of terrestrial flora (Madagascar, Seychelles). Only one strict endemic species was described in Juan de Nova. In the WIO. seabirds occur at high diversity and density ( 31 species, 7.4 million breading pairs) and the lles Eparses provide breeding and feeding grounds for a large part of their populations. The largest colony of sooty tern in the Indian Ocean occurs on Juan de Nova, Europa and Glorieuses with approx. 3 million breeding pairs. The study of foraging strategies of red-footed booby from Europa showed that theses birds varied the duration and range of their foraging trips according to the breeding cycle and environmental variability (Mendez et al., 2015). Trips cover a general foraging area of $33580 \mathrm{~km}^{2}$. Thus, marine birds support a strong link between a large marine area around their nesting island, being an efficient predator of fish and squid and a source of organic and inorganic nutrients for terrestrial and marine coastal primary producers. Among the other roles of seabirds related to their ability to form dense colonies and perform long trips, their ability to act as reservoirs and disseminators of parasites and pathogens was explored (McCoy et al., 2015). This study shed light on (i) the existence of relatively independent metacommunities of interacting species in the WIO, and (ii) the impact of seabird movements on parasite and pathogen circulation.

The lles Eparses program also allowed testing the application of coupling remote sensing, geomorphological and biocenosis attributes to define the diversity of reef habitats of Europa and Juan de Nova (Andrefouët, unpub. data). Large differences have been observed in the diversity of habitats of the two studied islands that can help to both biodiversity pattem understanding and conservation goals. Regarding present climatic induced threats on lles Eparses, the study of shoreline changes of Grande Glorieuse showed that despite the sea level has risen several centimeters in the last twenty years, the island has extended by 7.5 ha during the same period (Testut et al., 2015). This is the result of the predominance of shoreline aggradation due to sediment transfer from the sediment reservoir to the accumulation zone. As undisturbed or little disturbed systems, lles Eparses may allow to study natural processes that can contribute to increase resistance of reef-island to sea level rise or climatic induced extreme events such as cyclonic or austral swells. The problematic of the recording and survey of theses extreme events has been explored through terrestrial seismic stations that were able to efficiently detect and quantify swell, being thus a cheaper alternative to wave buoys for an automatic monitoring of oceanic events (Barruol et al., 2015). The geomorphology and sedimentology studies of the lles Eparses of the Mozambique Channel reveal that drowned terraces and emerged fossil reefs from the Glorieuses archipelago represent a potential unique record of past sea levels for the SW Indian Ocean (Jorry et al., 2015). While the lles Eparses are quite interesting ecological systems that offer a reference state to understand the consequences of anthropogenic impacts on island ecosystems, they also appear as excellent sites to observe both climatic changes and their effects.

Some of the above-mentioned scientific outcomes will also provide stakeholders with guidelines for the implementation of relevant management measures for the lles Eparses in order to maintain the integrity of ecosystems and face the multiple pressures they undergo. All results relevant to management are now included in conservation plans supported by the TAAF (e.g. Glorieuses Marine Natural Park Management Plan, Marine Turtle National Action Plan, Europa RAMSAR Management Plan and National Natural Reserve application file). Beyond the specific results of the "Iles Eparses" program presented in the papers of this special issue of Acta Oecologica, we wish to outline the fact that this program by its multidisciplinary opening allowed to reinforce the links among the scientific of different disciplines and contributed to build a knowledge background on the lles Eparses that will be useful for next fundamental and applied projects.

\section{What future for the Iles Eparses?}

TAAF strategy for sustainable development of the lles Eparses, which is still being built, must integrate all stakes at play: a complex regional context, an increasing pressure on the resources and the ambitions of the French government for these islands. The future of the lles Eparses is thus following a clear pathway whose main objective is to prevent biodiversity erosion with the development of conservation tools adapted to the specific context of each island and the development of sustainable activities. It 
includes a better control of industrial high-sea tuna fishery, artisanal fishery and tourism. Given the relatively low number of stakeholders accessing the area and the legislative specificity of TAAF, the management of the lles Eparses represents a unique opportunity to test and implement new models of sustainable use of the resources. Sharing this local experience through cooperation projects could benefit other countries in the Indian Ocean region and would especially make sense when applied to highly migratory species like tuna.

Research activities are essential to acquire the necessary knowledge and allow for the design of lles Eparses management strategy. The research consortium dedicated to the lles Eparses came to its end in December 2013 but the continuity of scientific research on the territory has been ensured by the construction of a new consortium and by (i) providing logistic support, (ii) facilitating the access to the islands and (iii) improving the working conditions for the scientists. In this purpose, laboratories are being renovated and equipped on each island. TAAF is also reinforcing national and international collaboration between scientists and managers through cooperation projects. Such a project, funded by the Xth regional European Development Fund, is currently taking place, aiming to the * sustainable management of the natural heritage in Mayotte and the lles Eparses *. In addition, the deployment of a larger panel of automatic recording stations and the organization of recurring monitoring surveys in the lles Eparses could serve as a basis for the development of an observatory for climate change and biodiversity in the Indian Ocean. Data would improve our understanding of the processes at stake in the region and could bring new insights for international organizations such as the Intergovernmental Panel on Climate Change (IPCC) or the Intergovernmental Platform on Biodiversity \& Ecosystem Services (IPBES).

\section{References}

Amandé, M.J. Chassot. E., Chavance, P., Planet, R., 2008a. Silky Shark (Carcharhinus Falciformis) Bycatch in the French Tuna Purse-seine Fishery of the Indian Ocean. IOTC-2008-WPEB-16.

Amande, M.J. Ariz. J.. Chassot, E. Chavance, P. Delgado de Molina, A., Gartner, D. Murua, H., Pianet, R., Ruiz, 1. 2008b. Bycatch and Discards of the European Purse Seine Tuna Fishery in the Indian Ocean. Estimation and Characteristics for the 2003-2007 Period. IOTC-2008-WPEB-12.

Amandé, MJ., Chassot, E, Chavance, P., Murua, H., Delgado de Molina, A., Bez, N. 2012 Precision in bycatch estimates: the case of tuna purse-seine fisheries in the Indian Ocean. ICES I. Mar. Sci. I. du Consell 69, 1501-1510.

Andrefouét, S., Chagnaud, N., Gauvin, C. Kranenburg. C.J. 2008. Altas des réecifs coraltiens de France Outre-Mer. Technical report. Centre IRD de Nouméa, p. 53 pp.

Barruol, G., Davy, C., Fontaine, F.R. Schlindwein, V., Sigloch, K., 2015, Monitoring austral and cyclonic swells in the "lles Eparse" (Mozambique Channel) from microseismic noise Acta Oecol. (This issue)

Battistini, R., Gayet, J., Jouannic, C, Labracherie, M., Peypouquet, J.P. Pujol, C., PujosLamy, A. Turon, J. 1976. Etude des sédiments et de la microfaune des iles Glorieuses (canal de Mozambique). Cahiers ORSTOM. Série Céologie 8, 147-171.

Borsa, P. Durand, J-D. Chen, W.1. Hubert, N.. Muths, D. Mou-Tham, G. Kulbicki M. 2015. Comparative phylogeography of the westem Indian Ocean reef tauna. Acta Oecol, (This issue).

Bourjea. J. Giccione, S. Lauret-Stepler, M. Marmoex, C. Jean, C. 2011. Les Des Eparses, vingt-cing ans de recherche sur les tortues marines. Bull. la Societe Herpétologique Fr. 140, 95-111.

Bourjea 1. Lapegue, S., Gagnevin, L Broderick. D., Mortimer, A. Ciccione S. Roos, D., Taquet, C. Grizel, H., 2007. Phylogeography of the green turtle, Chelonia mydas, in the SWIO. Mol Ecol. 16, 175-186.

Bourjea. J.. NeL R. Jiddawi, N.S., Koonjul, M.S., Bianchi, G., 2008, Sea turtle bycatch in the West Indian Ocean: review, recommandations and research priorities. West. Indian Ocean \& Mar. Sci. 7. 137-150.

Bouvy, M., Got, P., Domaizon, L, Pagano, M., Leboulanger, C, Bouvier, C., Carre, C. Roques, C, Dupuy. C, 2015. Plankton communities in the five lles Eparses (Western Indian Ocean) considered to be pristine ecosystems, Acta Oecol. (This issue).

Brownfield, M.E., Schenk, C... Charpentier, R.R., Klett, T.R., Cook, T.A. Pollastro, R.M. Tenryson, M.E. 2012. Assessment of Undiscovered Oil and Gas Resources of Four East Africa Geologic Provinces. (No 2012-3039). UIS. Geological Survey.

Caceres, S. 2003. Etude préalable pour le classement en Régerve Naturelle des ties
Eparses. Master Thesis. Universite de La Reunion, p. $234 \mathrm{pp}$.

Chabanet, P. Tessier, E. Durville, P. Mulochau, T, Rene, F. 2002. Peuplement ichtyologique des bancs de Geyser et Zelée (ockean indien occidental). Cybium 26 . $11-26$.

Chabanet, P. Durville, P., 2005. Reef fish inventory of Juan de Nova natural park (Western Indian Ocean). West. Indian Ocean J. Mar. Sci. 4. 145-162.

Chabanet, P. Bigot, L. Nicet, 1-B., Durville, P. Masse, L Mulochau, T. Russo. C, Tessier, E., Obura. D., 2015. Coral reef monitoring in the iles eparses. Mozambique channel (2011-2013). Acta Oecol. (This issue),

Chavance, P. Amande, M.J., Pianet, R., Chassot, E, Damiano, A., 2011. Bycatch and Discards of the French Tuna Purse Seine Fishery during the 2003-2010 Period Estimated from Observer Data. IOTC-2011-WPEB07-23.

Conand, C. Stöhr, S. Eleaume, M. Magalon, H. Chabanet, P., 2013a. The echinoderm fauna of europa, eparses Island(Scartered islands) in the Mozambique channel (South western indian ocean), Cah. Biol. Mar, 54, 499-504,

Conand, C., Mulochau, T. Chabanet, P., 2013b. The holothurian (Echinodermata) diversity of the glorieuses islands (Eparses islands. France. Mozambique channel). West Indian Dcean J. Mar. Sci. 12, 71-78.

Conand, C, Mulochau, T. Stöhr, S., Elèaume, M., Chabanet, P., 2015. inventory of Echinoderms in the lles Eparses (Europa, Glorieuses, Juan de Nova) Mozambique Channel, France. Acta Oecol. (This issue).

CBNM., 2013. Flore et végetations des iles Eparses, http:/ileseparses,cbnm.orgl.

Durville. P. Chabanet. P. 2010. Interridal rockpool fish in the Gloricuses Islands (West Indian Ocean). West. Indian Ocean J. Mar. Sci. 8, 95-104.

Durville, P. Chabanet, P, Quod, J.P. 2003. Visual census of the reef fishes in the natural Reserve of the glorieuses islands (Western indian ocean). West. Indian Ocean +. Mar. Sci. 2, 95-104.

Ersts, P. Kizka, \. Vély, M. Rosenbaum, H.C, 2011. Density, group composition, and encounter rates of humpback whales (Megaptera novaeangliae) in the eastern Comoros Archipelago. J Cetacean Res. Manag. 3, 175-182,

Fricke, R., Durville, P. Bernardi, G., Borsa, P., Mou-Tham, G., Chabanet, P. 2013. Cheklist of the shore fishes of europa island. Mozambique channel, southwestem Indian Ocean, including 302 new records. Stuttg. Beitráge zur Naturkd. A, Neue Ser 6, 247-276.

Gravier-Bonner, N. Bourmaud, C, 2004. Hydroids (Cnidaria, Hydrozoa) of coral reefs: preliminary results on community structure, species distribution and reproductive biology in the iles Glorieuses (southwest indian Ocean), In: Proceedings of 10th international Coral Reef Symposium. Okinawa Japan. June 28July 2,2004, pp. $188-196$.

Gravier-Bonnet, N. Bourmaud, C., 2006. Hydroids (Cnidaria, Hydrozoa) of coral reefs: preliminary results on community structure, species distribution and reproductive biology in fuan de Nova island (southwest Indian Ocean). West. Indian Ocean I. Mar. Sci. 5, 123-132.

Jorry. S.J. Camoin, G.F., Jouet, G. Le Roy, P., Vella, C, Courgeon, S. Prat, S. Fontanier, C. Paumard, V., Boulle, I., Caline, B., Borgomano, 1- 2015. Modern sediments and Pleistocene reefs from isolated carbonate platforms (Iles Eparses. SW Indian Ocean); a preliminary study. Acta Oecol. (This issue).

Kiszka. J. Jamon, A., Wickel, f. 2009a. les requins dans les iles de l'ocḱan indien Occidental : Biodiversite, distribution et interactions avec les activités humaines. Rapport Mayshark pour le compte de WWF France, p. 47 pp.

Kiszka, J.. Bergeren. P. Rosenbaum, H.C., Cerchio, S. Rowat, D., Drouot-Dulau, V. Razafindrakoto, Y. Vely, M. Guissamulo, A. 2009b. Cetaceans in the Southwest Indian Ocean: a Review of Diversity. Distribution and Conservation Issues. Technical report. International Whaling Commission.

Laran, S, Van Canneyt, O., Doremus, G., Mannocci, L, Ridowx, V., Watremez, P., 2012. Distribution et abondance de la mégafaune marine dans le sud-ouest de l'océan Indien tropical REMMOA-Océan Indien. Technical report. Agence des Aires Marines Protégées, p. 170 pp.

le Corre, M. Danckwerts, D, K., Ringler, D., Bastien, M_, Or lowsti, S, Morey Rubio, C, Pinaud, D. Micol, $T_{n}, 2015$. Seabird recovery and vegetation dynamics after Norway rat eradication at Tromelin Island, Westem Indian Ocean. Biol. Conserv. 185, 85-94.

Le Manach, F, Pauly, D, 2015. First estimate of unreported catch in the french lles Epurses, 1950-2010. In: Le Manach, F., Pauly, D, (Eds.), Fisheries Catch Reconstructions in the Westem Indian Ocean, 1950-2010. Fisheries Centre Research Reports 23, Fisheries Centre, University of British Columbia. pp. $27-35$.

Martio, L. Zubia, M., 2012 Seaweed diversity in the Mozambique channel : an expedition to Europa kland. Newst. Phycol. Soc. South. Afr. 78, 6-8.

Mattio, L. Zubiac, M.. Maneveldt, 0.G.W., Anderson, R.J., Boltoon, J\}, de Gaillande. C. De Clerck, O., Payri, C.E, 2015, Marine flora of the lles Eparses (Scattered Islands): a longitudinal transect through the Mozambique Channel. Acta Oecol. (This issue).

McCoy, K.D. Dietrich. M. Jaeger, A., Wilkinson. D.A. Bastien. M. Lagadec. E., Boulinier. T., Pascalis, H. Tortosa, P., Le Corre, M. Dellagi, K. Lebarbenchon. C, 2015. The role of seabirds of the lles Eparses as reservoirs and disseminators of parasites and pathogens. Acta Oecol. This issue.

Mendez, L., Cotte, C. Pruder, A, Weimerskirch, H., 2015. Variability in foraging behaviour of red-footed boobies nesting on Europa island. Acta Oecol. (This issue).

Mulochau, T. Conand, C. Quod, LP. 2007. Les holothuries et autres echinodermes du Banc de Geyser (Mayotte - Océan Indien), La Beche de mer. Bull la CPS 26, 7-13.

Mulochau, T. Conand, C. 2009. Les holothuries et autres èchinodermes des tiles Glorieuses (iles eparses - Océan Indien). La Béche de mer. Bull. la CPS 28, 
34-39.

Muths, D. Gouws G. Mwale, M. Tessier, E, Bourjea, I. 2012. Genetic connectivity of the reef fish Lutjants kesmira at the scale of the western Indian Ocean. Can. I Fish Aquatic Sci, 69, 842-853.

Muths, D., Tessier, E, Gouws, G., Craig, M., Mwale, M., Mwaluma, J4 Mwandya, A., Bourjea, 1.. 2011. Restricted dispersal of the reef fish Myripristis bemdti at the scale of the SW Indian Ocean. Mar. Fcol. Prog. Ser. 443, 167-180.

Obura, D., Church. J. Gabrie, C. 2012 Assessing Marine World Heritage from an Ecosystem Perspective: the Western Indian Ocean. World Heritage Centre, United Nations Education, Science and Cultural Organization (UNESCO), p. 124 pp.

Parnaudeau, R. 2008. Biodiversite entomologique des lles Eparses. Technical report. Museum d'Histoire naturelle de La Reunion, p. 110 pp.

Pison, G., 2015. Tous les pays du monde (2015). Popul. Socieres 525, 1-8.

Poisson, F., Filmalter, JD., Vernet, A.., Dagom, L, 2014. Mortality rate of silky sharks (Carcharhinus faldformis) caught in the tropical tuna purse seine fishery in the Indian Ocean. Can. J. Fish. Aquatic Sci. 71, 795-798.

Poupin, 1. 2015. First inventory of the Crustacea (Decapoda, Stomatopoda) of Juan de Nova Island with ecological observations and comparison with nearby islands in the Mozambique channel (Furopa, Glorieuses, Mayotte). Acta Oecol. (This issue).

Poupin, L. Zubia, M., Gravier-Bonner, N., Chabanet, P., Malay, M. 2012. Illustrated checklist of the Decapoda at europa island. West. Indian Ocean J. Mar. SCi. 11. $1-25$.

Probst. J-M. 1997. Inventaire des reptiles indigenes de La Reunion, de Mayotte et des lles Eparses (Ocean Indien). Bull. Phaet, 6, 68-70.

Probst, J-M.-1999, Guide préliminaire des reptiles sédentaires de l'ile de La Rẻunion et des iles éparses avec une liste des especes migratrices et erratiques répertoriées depuis 10 ans. Bull. Phacthon $10.57-91$.

Quod, J.P. Garnier, R., 2004. A preliminary assessment of the coral reefs of Europa (Mozambique channel), Reef. Encount. 32, 23-25.

Quod, JP., Barrere, A., Chabanet, P., Durville, P.. Nicet, J,B, Gamier, R, 2007, La situation des récifs coralliens des iles Eparses françaises de Pocéan Indien. Revue Ecol. (Terre Vie) 62, 3-16
Ringler, D. Russell, JC, Le Corre, M, 2015. Trophic mles of black rats and seabird impacts on tropical islands: mesopredator release or hyperpredation Biol Consery 185, 75-84.

Ringler, D., Russell, J.C. Jaeger, A., Pinet, P., Bastien, M, Le Corre, M., 2014. Invasive rat space use on tropical islands: Implications for bait broadcast. Basic Appl. Ecol. 15, 179-186,

Russell JC Le Corre, M. 2009. Introduced mammals impacts on seabirds in the lles Eparses. Westem Indian Ocean. Mar. Ornithol 37, 121-128.

Sanchez. M. Probst, J.-M. 2014. Inventaire, distribution et écologie des reptiles terrestres de Mile d'Europa (Canal du Mozambique), Outil de gestion pour la Réserve Naturelle d'Europa. Technical report. Nature Ocean Indien, p. $47 \mathrm{pg}$.

Schouten, M.W., De Ruijter, W., Van Leeuwen, P., Ridderinkhof, H., 2003. Eddies and variability in the Mozambique Channel. Deep Sea Res. Part II Top. Stud. Oceanogr. 50, 1987-2003.

Testut, L, Duvat, V., Ballu, V., Fernandes, R.MS., Pouget, F., Salmon, C. Dyment, J, 2015. Shoreline changes in a rising sea level context: the example of Grande Glorieuse, scattered islands. Western Indian Ocean. Acta Oecol. (This issue).

Visram, S. Yang, M.C. Pillay, R.M. Said, S. Henriksson, O., Grahn, M. Chen, C.A. 2010. Genetic connectivity and historical demography oh the blue barred parrotfish (Srarus ghobban) in the western Indian Ocean. Mar. Biol. 157, 1475-1487.

Weimerskirch, H., Le Corre, M., Jaquemet. S. Potier, M., Marsac, F, 2004. Foraging strategy of a top predator in tropical waters: great frigatebirds in the Mozambique Channel Mar. Ecol. Proz Ser. 275, 297-308,

Wickel, J., Quod. J.P., Nicet. I.-B., Chabanet. P. Jamon. A. Durville, P., Mulochau. T., Tessier, E., Arnaud, J.P. Dinhut, V., 2009. La lente degradation du banc du Geyser : dix années d'évolution des peuplements de poissons. Univers Maoné 12 30-37.

Wickel, 」. Jamon, A, Kiszka, 」 Laysiac, K., Nicet, LB, Sauvignet, H. Seret, B., 2010. Structure des communautés de requins et autres poissons prédateurs des bancs récifaux de Geyser, Zélèe et Iris (Canal de Mozambique). Technical report indian Ocean Shark Research Group (MAYSHARK), Direction de I'Agriculture et de ta Forèt de Mayotte, p. $21 \mathrm{pp}$.

Zubia, M. Turquet, J Golubic, S. 2015. Benthic cyanobacterialdiversity of iles eparses (Scattered islands) in the Mozambique channel. Acta Oecol (This issue) 